\title{
ANNOUNCEMENT
}

\section{THE INTERNATIONAL CODE OF ZOOLOGICAL NOMENCLATURE}

The following Opinions (listed by number) have been published recently by the International Commission on Zoological Nomenclature.

Bulletin of Zoological Nomenclature, volume 37, part I, 8 May 1980

Opinion no.

2081 Mesoplodon Gervais, I850 (Mammalia: Cetacea); proposed conservation.

2129 Prodorylaimus Andrássy, I959 (Nematoda); proposed designation of a type species.

2268 Acmaea limatula Carpenter, I864 (Mollusca: Gastropoda); proposed conservation.

2289 Rafinesque, 1822 'On the turtles of the United States' (Reptilia: Testudines); proposed suppression.

Comments should be sent in duplicate (if possible within 6 months of the date of publication of this notice), citing case number to:

R. V. Melville, The Secretary, International Commission on Zoological Nomenclature, c/o British Museum (Natural History),

Cromwell Road,

London, $\mathrm{SW}_{7}$ 5BD,

England.

Those received early enough will be published in the Bulletin of Zoological Nomenclature. 